Average quasi-valence numbers of some organic compounds

\begin{tabular}{lll}
\hline Name of compound & Molecular formula & $Z^{*}$ \\
\hline g) Penicillin group of antibiotics & \\
Penicillin BT & $\mathrm{C}_{14} \mathrm{H}_{22} \mathrm{O}_{4} \mathrm{~N}_{2} \mathrm{~S}_{2}$ & 2.82 \\
Penicillin N & $\mathrm{C}_{14} \mathrm{H}_{21} \mathrm{O}_{5} \mathrm{~N}_{3} \mathrm{~S}$ & 2.98 \\
Penicillin O & $\mathrm{C}_{13} \mathrm{H}_{18} \mathrm{O}_{4} \mathrm{~N}_{2} \mathrm{~S}_{2}$ & 2.97 \\
Penicillin S & $\mathrm{C}_{14} \mathrm{H}_{18} \mathrm{O}_{4} \mathrm{~N}_{2} \mathrm{~S}_{2} \mathrm{Cl}$ & 2.95 \\
Penicillin V & $\mathrm{C}_{16} \mathrm{H}_{18} \mathrm{O}_{5} \mathrm{~N}_{2} \mathrm{~S}$ & 3.05 \\
Penicillin V potassium salt & $\mathrm{C}_{16} \mathrm{H}_{17} \mathrm{O}_{5} \mathrm{~N}_{2} \mathrm{SK}$ & 3.05 \\
\hline
\end{tabular}

$\dagger$ Essential amino acids are marked with $(+)$.

provoke some questions. Does the large deviation from $Z^{*} \simeq 3.0$ necessarily lead to less penicillin-like antibiotic activity or not? What would happen if one attaches low or high $Z^{*}$ groups, like $\mathrm{CH}_{3}$ or $\mathrm{NO}_{2}$, for example, to a normal penicillin molecule? Does a small modification of the given molecule, which causes a slight change of its $Z^{*}$, create a new effective drug which can solve the problem of resistance to the original antibiotic already used? These questions and similar ones require new investigations and better understanding of the $Z^{*}$ role.

The fact established in this work that antibiotics inhibiting protein synthesis possess well-defined $Z^{*}$ values (overlapping with the $Z^{*}$ values of amino acids) tells us that the average electronic charge carried by molecules plays an important role in their activity. Most probably during the transport of molecules, or their approach to the reaction centres, some preselection on the basis of their average quasi-valence numbers occurs. More complex characteristics (structural characteristics of molecules, which play a decisive role in molecular interactions in living matter) come into play after the molecular preselection. The selection of molecules according to their $Z^{*}$ values could be explained by the dependence of electrostatical interactions on the potential, for which it was shown ${ }^{1}$ that it is a function only of the $Z^{*}$.

If more detailed investigations of the antibiotic activity $\mathrm{Z}^{*}$ correlation give support to our findings, we shall get guidance for design and selection of new antibiotic drugs Making necessary chemical modifications of selected substances, we could obtain the desired $Z^{*}$ values, and perhaps accelerate our efforts to create new effective antibiotics. The other benefit of new investigations within the framework of simple valence theory might be connected with better understanding of antibiotic behaviour in living matter $^{8}$.

1 V. Veljković and D.I. Lalović, Experientia 33, 1228 (1977)

2 V. Veljković and V. Ajdačić, Experientia 34, 639 (1978).

3 In case of halogen elements instead of $\mathrm{Z}=7, \mathrm{Z}=1$ should be used.

4 J.S. Glasby, Encyclopaedia of Antibiotics. John Wiley \& Sons, New York 1976.

5 S. Pestka, in: Molecular Mechanism of Protein Biosynthesis, p. 467. Ed. H. Weissbach and S. Pestka. Academic Press, New York 1977.

6 E.F. Gall, E. Cundliffe, P.E. Reynolds, M.H. Richmond and M.J. Waring, in: The Molecular Basis of Antibiotic Action, p. 173. John Wiley \& Sons, New York 1972.

$7 \mathrm{Y}$. Miura, Antibiotics and Replication - Table Document No.4954, published by Calbiochem, P.O. Box 12087, San Diego, Cal. 92112, USA.

8 V. Veljković and V. Ajdačić, to be published.

Note added in proof: Dr. S. Pestka (private communication) for althiomycin used the formula $\mathrm{C}_{16} \mathrm{H}_{17} \mathrm{~N}_{5} \mathrm{O}_{6} \mathrm{~S}_{2}$ as given in $\mathrm{J}$. Antibiot. $28,286(1975)$, and for sparsomycin $\mathrm{C}_{13} \mathrm{H}_{19} \mathrm{~N}_{3} \mathrm{O}_{5} \mathrm{~S}_{2}$, as reported in J. Am. chem. Soc. 92, 417 (1970). The corresponding $Z^{*}$ are: 3.35 and 3.05 , instead of 3.34 and 3.30 , respectively.

\title{
The inhibitory effects of a dermal extract upon igranulation tissue ${ }^{1}$
}

\section{T. Hanks and E. O. Smith}

\section{School of Dentistry and Dental Research Institute, University of Michigan, Ann Arbor (Michigan 48109, USA), 11 October} 1977

Summary. Injection of a water-soluble dermal extract into adult rats resulted in depression of DNA synthesis in granulation tissue at 3 different sites of injury, but not in kpithelium. This suggests that connective tissue proliferation may be controlled in part by a chalone-like mechanism.

In vitro studies have shown that factors in cell extracts and dialyzed media from cell cultures can inhibit the growth of WI-38 cells and human cutaneous fibroblasts ${ }^{2,3}$. These studies suggest that a tissue-specific, species non-specific, inhibitory factor may be responsible. However, there are no published reports to support the hypothesis that such a mechanism is operating in vivo. Our experiments demonstrate tissue-specific inhibition of connective tissue promechanism is operating in vivo. Our experiments demonstrate tissue-specific inhibition of connective tissue proliferation in healing wounds at 3 different sites of injury in young adult male rats by a tissue extract of neonatal rat dermis. Species specificity of the tissue extract has not been tested.

Material and methods. In order to prepare a dermal tissue extract free of contaminating epidermis, approximately 100 neonatal Sprague-Dawley rats were decapitated and their skins removed. These skins were immersed for $30 \mathrm{sec}$ in $55^{\circ} \mathrm{C}$ water and cooled on ice ${ }^{4}$. Following separation of dermis from epidermis with forceps, the 2 portions of each skin were placed in separate containers of liquid nitrogen. The accumulated dermis tissue was powdered with mortar and pestle, homogenized in $0.02 \mathrm{M}$ Tris- $\mathrm{HCl}$ buffer at $\mathrm{pH}$ 7.15 , and centrifuged at $10,800 \times \mathrm{g}$ for $30 \mathrm{~min}$ at $4^{\circ} \mathrm{C}$. The supernate was dialyzed against $0.02 \mathrm{M}$ Tris- $\mathrm{HCl}$ buffer, lyophylized and stored at $-20^{\circ} \mathrm{C}$ until ready for use. The dermal extract (DE) was reconstituted with $0.02 \mathrm{M}$ Tris$\mathrm{HCl}$ buffered saline, $\mathrm{pH} 7.15$ to a protein concentration of $10 \mathrm{mg} / \mathrm{ml}^{5}$. Neonatal liver extract (LE) was prepared in the same manner.

5 surgical excisions were made in each experimental and control animal. A back wound, $1 \mathrm{~cm}^{2}$, was made to the depth of the fatty s.c. tissue (figure A). Full thickness excisional wedges were removed from the pinnae of both ears. They were $3 \mathrm{~mm}$ wide at the edge and extended $4 \mathrm{~mm}$ deep (figure B). And finally, bilateral palatal excisions were made beginning at a line $1 \mathrm{~mm}$ medial to each maxillary $1 \mathrm{st}$ molar and extending to the cemento-enamel junction of the tooth (figure $\mathrm{C}$ ). The effects of the tissue extracts upon proliferation of granulation tissue at each wound site, as well as maxillary mucosal epithelium, was evaluated by autoradiography. (Tritiated) thymidine $\left(0.5 \mu \mathrm{Ci}^{3} \mathrm{HTdR} / \mathrm{g}\right.$ b. wt, sp. act. $6.7 \mathrm{Cl} / \mathrm{mmole}$ was injected i.p. $1 \mathrm{~h}$ before sacrifice in all cases. In a preliminary experiment, nuclear 

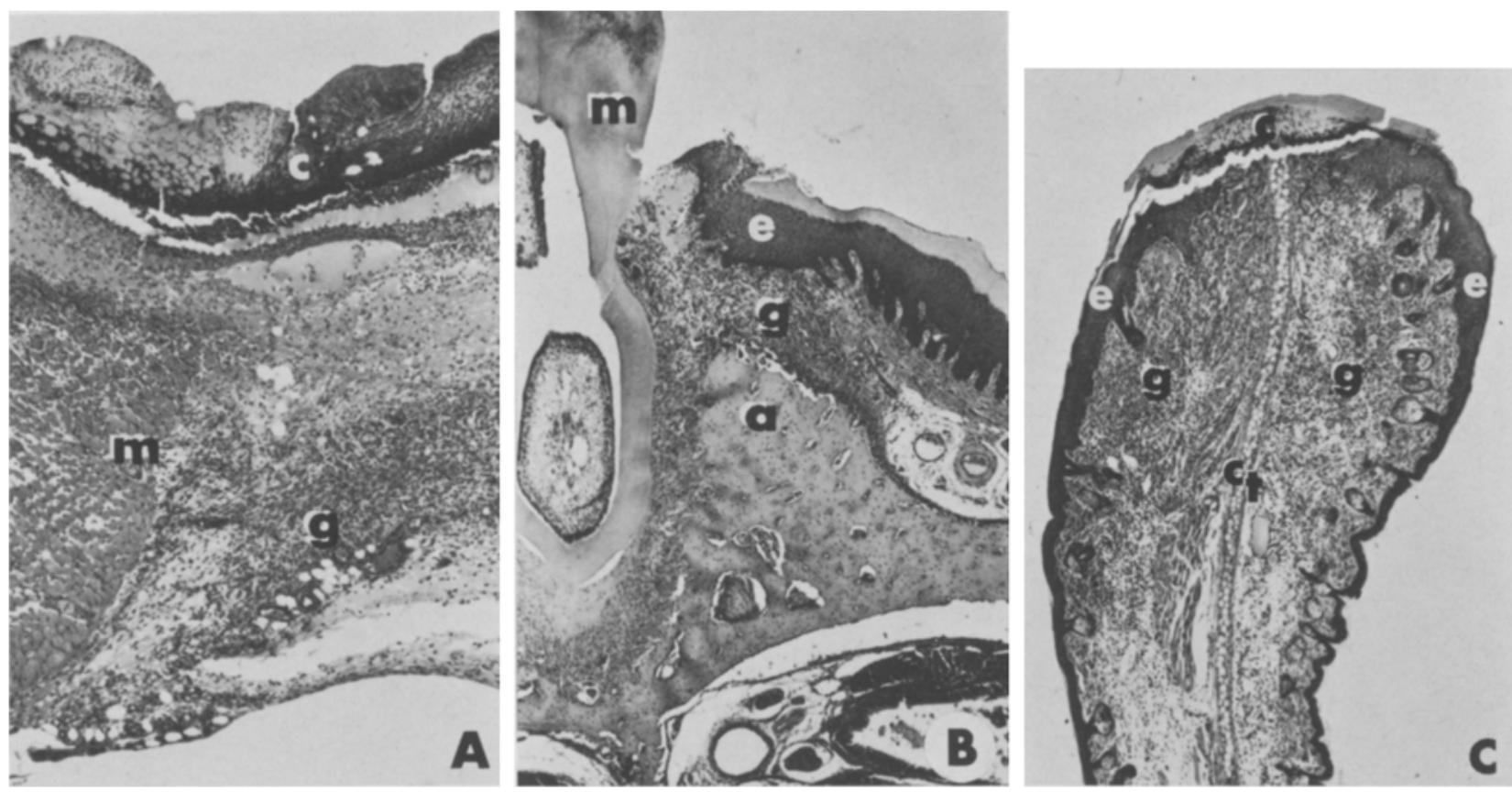

Figures A, B and C. 3 sites of injury in each experimental and control animal, $72 \mathrm{~h}$ following surgical injury. $A$ Back wound with clot (c) overlying dermis containing the sectioned panniculus carnosus muscle $(\mathrm{m})$ and fatty s.c. connective tissue from which early granulation tissue $(\mathrm{g})$ was derived. Migrating surface epithelium was at the level of the clot, but is not shown $(\times 41)$. B Maxilla just palatal to lst molar $(\mathrm{m})$, showing epithelium (e) and connective tissue in the area of the wound. Granulation tissue ( $\mathrm{g}$ ) was most prominent in a connective tissue zone superficial to the peak of alveolar (a) bone $(\times 80)$. C 1 side of ear wound. A clot (c) covered the sectioned edges. Cartilage (ct) separates the 2 portions of connective tissue of ear, each of which is covered with hair-bearing epithelium (e). Granulation tissue (g) began in fatty connective tissue to the right of the cartilage or adjacent to the muscle to the left of the cartilage $(\times 37)$.

labeling of granulation tissue in each wound site was greatest on the 3 rd day following surgical injury to that site. Therefore, using day $3(72 \mathrm{~h})$ as the end point of the experiment, $1 \mathrm{ml}$ of either DE or LE $(10 \mathrm{mg}$ protein $/ \mathrm{ml})$ was injected s.c. into the necks of our experimental animals at each of 6 time intervals prior to sacrifice: $24,20,16,12,8$ and $4 \mathrm{~h}$. 4 control animals were injected $24 \mathrm{~h}$ before sacrifice with $1 \mathrm{ml}$ sterile saline only. All animals were sacrificed under ether anesthesia at $10.00 \mathrm{~h}$.

The tissue was fixed by routine methods, dehydrated and embedded in paraffin, and step serial-sectioned at $8 \mu \mathrm{m}$ thickness. After dipping in Kodak NTB-2 nuclear emulsion, the slides were exposed for 3 weeks, processed, stained with hematoxylin and eosin and viewed at magnification, $\times 400$. Granulation tissue appeared consistently in the same zones in each wound site at each time period. The average number of labelled nuclei per high power field (area $=0.0625 \mathrm{~mm}^{2}$ ) was determined in the granulation tissue at each time period. In addition, labelled basal and parabasal nuclei per $0.25 \mathrm{~mm}$ linear surface distance of maxillary mucosal epithelium was determined at the same magnification. This method of evaluation of multiple sections was preferred to the labeling index method (labelled nuclei/ 1000 cells) because the zones to be evaluated were well defined, while the staining intensity of the cells varied to some extent.

Results and discussion. Autoradiographs from animals injected with DE at $16 \mathrm{~h}$ consistently showed reduced nuclear labeling in the granulation tissue zones when compared to control slides. The most dramatic depression of nuclear labeling was observed in granulation tissue in wounds of the back and maxilla. Nuclear labeling was depressed $58 \%$

Effect of DE and LE upon connective tissue and epithelial nuclear labeling

\begin{tabular}{|c|c|c|c|c|c|c|c|}
\hline \multirow{2}{*}{$\begin{array}{l}\text { Sample and injection time } \\
\text { (h) }\end{array}$} & \multicolumn{7}{|c|}{ Labeled nuclei $(\overline{\mathrm{X}} \pm \mathrm{SEM}) / 0,0625 \mathrm{~mm}^{2}$} \\
\hline & $\begin{array}{l}\mathrm{DE} \\
\mathrm{G}_{\mathrm{b}}\end{array}$ & $\mathrm{G}_{\mathrm{m}}$ & $\mathrm{G}_{\mathrm{e}}$ & $E_{m}$ & $\begin{array}{l}L E \\
G_{b}\end{array}$ & $\mathrm{G}_{\mathrm{m}}$ & $E_{m}$ \\
\hline$\overline{\mathrm{E}-4^{+}}$ & $32.3 \pm 4.1$ & $33.3 \pm 3.3$ & $32.8 \pm 4.0$ & $24.7 \pm 1.7$ & $40.4 \pm 4.6$ & $44.8 \pm 4.4$ & $30.4 \pm 5.2$ \\
\hline $\mathrm{E}-8$ & $38.7 \pm 2.4$ & $30.3 \pm 1.9$ & $27.4 \pm 2.4$ & $28.5 \pm 1.9$ & $36.8 \pm 6.7$ & - & $15.1 \pm 4.2$ \\
\hline E-12 & $35.7 \pm 6.6$ & $33.5 \pm 5.9$ & $27.2 \pm 2.9$ & $27.4 \pm 5.3$ & $30.4 \pm 4.2$ & $42.5 \pm 4.6$ & $21.9 \pm 3.4$ \\
\hline E-16 & $15.2 \pm 4.6^{* *}$ & $14.7 \pm 1.9^{*}$ & $20.8 \pm 2.0^{* * *}$ & $22.8+4.0$ & $36.7 \pm 4.5$ & $47.5 \pm 4.0$ & $18.1 \pm 3.7$ \\
\hline E-20 & $15.9 \pm 5.8^{* * *}$ & $24.9+3.9^{* *}$ & $19.4+2.3^{* * *}$ & $22.7 \pm 2.6$ & $38.3+7.7$ & $44.9 \pm 5.3$ & $20.8 \pm 2.5$ \\
\hline E-24 & $23.6 \pm 4.0$ & $33.3 \pm 5.4$ & $23.8 \pm 2.9$ & $17.9 \pm 2.1$ & $38.7 \pm 5.8$ & $53.8 \pm 10.3$ & $26.1 \pm 6.4$ \\
\hline SC-24 & $36.5 \pm 2.4$ & $45.5 \pm 4.1$ & $27.5 \pm 1.5$ & $25.0 \pm 2.6$ & $36.6 \pm 2.4$ & $45.5 \pm 4.1$ & $25.0 \pm 2.6$ \\
\hline
\end{tabular}

Effects of $10 \mathrm{mg}$ of either neonatal dermal extract (DE) or neonatal liver extract (LE) on healing wounds of back (b), maxillary mucosa $(\mathrm{m})$ and ear (e). The data represents average number of labeled nuclei per high power field of granulation tissue $(\mathrm{G})$ or per $0.25 \mathrm{~mm}$ linear surface distance of epithelium (E).

+ Experimental animals (e.g. E-4) were injected with the extracts at various time intervals before sacrifice; surgical control animals (s.c.) were injected with $1 \mathrm{ml}$ sterile saline $24 \mathrm{~h}$ before sacrifice. ${ }^{*}$ Student's t-test of significance: Exp. vs control; $\mathrm{p}<0.001 ;{ }^{* *} 0.02>\mathrm{p}>0.01$; $* * 0.05>p>0.02$; all other values, $p>0.05$. 
and $68 \%$, respectively, as compared to control values (table). For the same time period, granulation tissue of ear wounds were depressed only $25 \%$ below controls. Less depression of nuclear labeling was observed in animals injected with DE at $20 \mathrm{~h}$ than at $16 \mathrm{~h}$, and even less in those injected at $24 \mathrm{~h}$. DE did not cause a significant depression of nuclear labeling of maxillary palatal epithelium. LE injections did not depress nuclear labeling of connective tissue or epithelium significantly at any time period.

The reduced proliferation in granulation tissue following DE injection appeared to be discrete and consistent in its timing and apparently specific for connective tissue. This suggests that some factor in the DE may have specifically interrupted or slowed a particular stage in the cell cycle of proliferating connective tissue cells, rather than having caused a generalized cytotoxic effect. Studies with other experimental models have shown that early events following stimulation are important to later DNA synthesis. Inhibition of RNA synthesis $0-4 \mathrm{~h}$ after rat hepatectomy depressed DNA synthesis in liver 12-18 h later $^{6}$. And, inhibition of protein synthesis 1-8 h after isoproterenol stimulation of mouse salivary gland resulted in depressed DNA synthesis $20 \mathrm{~h}$ later ${ }^{7}$. The $G_{1}$ chalone for mammalian epidermis has been shown to depress DNA synthesis in mouse epidermis in vivo maximally between 9 to $20 \mathrm{~h}$ after injection ${ }^{8,9}$. This study presents the 1st in vivo evidence (to our knowledge) of a dermal chalone-like substance, present even in neonatal rat dermis, which is capable of suppressing DNA synthesis in proliferating connective tissue In a lower physiologic concentration, this substance may take part in a negative feedback mechanism to control growth and proliferation of granulation tissue in the healing wound. Further studies are necessary to determine whether this substance is active in embryologic or neoplastic connective tissue growth.

1 Supported by the Dental Research Institute (NIDR parent grant No. DE 02 731) and the School of Dentistry, University of Michigan. We thank J. Pringle, L. Brinkley, and C. Mistretta for constructive criticism of the manuscript.

2 J.C. Houck, R. L. Weil and V.K. Sharma, Nature New Biol 240,210 (1972).

3 J.C. Houck, in: Trace Components of Plasma: Isolation and Clinical Significance, p. 193. Alan R. Liss Inc., New York 1976.

4 J.M. Marrs and J.J. Voorhees, J. invest. Derm. 56, 174 (1971).

5 O.H. Lowry, N.J. Rosebrough, A.L. Farr and R.J. Randall, J. biol. Chem. 193, 265 (1951)

6 M. Fujioka, M. Koga and I. Lieberman, J. biol. Chem. 238, 3491 (1963).

7 T. Sasaki, G. Litwack and R. Baserga, J. biol. Chem. 244, 4831 (1969).

8 H. Hennings, K. Elgjo and O.H. Iverson, Virchows Arch Zellpath. 4, 45 (1969).

9 F. Marks, in: Chalones: Concepts and Current Researches, p. 79. Natl Cancer Inst. Monograph No.38 1973.

\title{
Inhibition of reserpine-induced PGO waves in the cat by ergot derivatives
}

\author{
P.E. Züger, J.M. Vigouret and D. M. Loew \\ Biological and Medical Research Division, Sandoz Ltd, CH-4002 Basle (Switzerland), 16 September 1977
}

Summary. The number of reserpine-induced PGO waves in the cat is decreased by administration of ergot derivatives. The inhibition is dose-dependent and the various ergot derivatives show differing potencies. The action of the ergot derivatives may result from stimulation of central serotonin receptors. In addition, possible involvement of dopaminergic systems is discussed.

PGO waves, a characteristic phasic electrical activity recorded from the pons, the lateral geniculate bodies and the occipital cortex occur spontaneously just prior to and during paradoxical sleep in the cat, but are also elicited by pharmacological agents such as reserpine which deplete central monoamine stores ${ }^{1-3}$. PGO waves induced by reserpine, the benzoquilizine derivative Ro 4-1284 or p-chlorophenylalanine are inhibited by 5-hydroxytryptophan (5HTP) or by the lysergic acid derivatives LSD-25, 2-bromoLSD and methysergide ${ }^{1,4-7}$. Our investigations indicate that the inhibition of reserpine-induced PGO waves is a common property of several centrally active ergot derivatives. Experimental. The studies were carried out under local anaesthesia in adult male cats $(2.5-3.5 \mathrm{~kg})$ which were immobilized by gallamine and artificially respired. Reserpine, $0.5 \mathrm{mg} / \mathrm{kg}$ i.p. was administered $5 \mathrm{~h}$ before recording. Under ether anaesthesia the trachea, both femoral veins and a femoral artery were cannulated for artificial respiration, i.v. drug administration and continuous recording of blood pressure, respecitvely. The head of the animal was placed in a stereotactic apparatus. Pressure points and wound edges were infiltrated with novocaine. The electrocorticogram (ECoG) was recorded from screw electrodes over the frontal, sensorimotor and visual cortex. The PGO waves were recorded from bipolar concentric electrodes of $0.5 \mathrm{~mm}$ diameter inserted in both lateral geniculate bodies using the Horsley-Clark coordinates $A+7.0, L \pm 10.5$, $\mathrm{H}+3.5$ and adjusted to receive optimal electrical signals. PGO waves were simultaneously registered with the ECoG, blood pressure and heart rate on a Grass model 7 poly- graph. PGO waves of more than $100 \mu \mathrm{V}$ amplitude were counted and printed out as cumulative number per $10 \mathrm{~min}$. During the experiment the animals were maintained at $37.5^{\circ} \mathrm{C}$.

Test substances, dissolved either in $0.9 \%$ saline or in diluted tartaric acid solution, were administered into the femoral vein. After a pre-drug control period, the drugs were given in increasing doses at intervals of $30 \mathrm{~min}$. Changes in the number of PGO waves counted during each treatment period were compared to the pre-drug control value. At least 3 experiments were performed with each substance.

Investigated ergot derivatives. Dihydroergotoxine methanesulphonate (Hydergine ${ }^{\circledR}$ ), dihydroergotamine methanesulphonate, 13-bromo-9,10-dihydroergotamine hydrogentartrate (BZ 23-467), dihydroergostine hydrochloride (DE 145), dihydroergonine hydrochloride (DN 16-457), dihydro- $\beta$-ergosine (DQ 27-422), d-lysergic acid diethylamide tartrate (LSD-25), methysergide hydrogenmaleinate, 6-methyl-8 $\beta$-[4-(p-methoxyphenyl)-1-piperazinyl-methyl]9-ergolene dimethanesulphonate (PTR 17-402), 6-methyl$8 \beta$-[2-pyridylthiomethyl]-ergolene tartrate (CF 25-397), 6methyl-8a-cyanomethyl-ergoline methanesulphonate (CM 29-712), 2-bromo- $a$-ergocryptine methanesulphonate (bromocriptine, CB 154).

Results and discussion. The onset of a regular PGO wave pattern in the recordings from the lateral geniculate bodies of the cat, comparable to the stage 2 described by Brooks and Gershon ${ }^{2}$, was observed 3-4 $\mathrm{h}$ after reserpine administration. At the same time low-voltage fast activity was seen in the ECoG. The frequency of PGO waves $\left(30-50 \mathrm{~min}^{-1}\right)$ 